\title{
Konsepsi Hadis dan Sunnah Prespektif Fazlur Rahman
}

\author{
Habieb Bullah \\ Institut Pesantren KH.Abdul Chalim Mojokerto
}

habibhabieb@gmail.com

\begin{abstract}
;
The emergence of world liberal Muslim thinkers today such as Fazlur Rahman (Pakistan) has become a discourse among observers of Islamic science. Fazlur Rahman is one of the neo-modernist intellectual figures. In terms of religion, he had experienced deep intellectual anxiety. According to him, Muslims have closed the doors of ijtihad, so what happened was extraordinary intellectual stagnation. In the end, Islam became a set of frozen doctrines and it is certainly difficult to appear in giving answers to the problems of the ummah amid the wave of modernity. For this reason, he takes different steps in expressing and formulating the concepts of sunnah and hadith, which is a response and form of criticism of the views of Muslims so far. One of the concepts offered by Fazlur Rahman is related to the hadith and sunnah. He considers that the hadith and sunnah need to be distinguished by a number of reasons stated. According to him the hadith is only a text that is raw or actually comes from the Prophet. Whereas the sunnah is the actualization or interpretation of the hadith text and must be adjusted to the historical setting when it comes to understanding a hadith. This shows that what is written in the hadith is not all said to be sunnah. However, not all sunnah are recorded in the hadith. Therefore, when hadith has been corrupted, since then, the sunnah has not developed. He is attached to the books scheduled. This research uses descriptive-analysis method which contains an analysis of the concept of fazlur rahman about the Sunnah hadith. This research produced a critical view of Fazlur Rahman about the concepts of hadith and sunnah.
\end{abstract}

Keywords; Hadith, Sunnah, Fazlur Rahman

\begin{abstract}
Abstrak
Munculnya pemikir-pemikir Muslim liberal dunia saat ini seperti Fazlur Rahman (Pakistan) telah menjadi wacana tersendiri di kalangan pemerhati keilmuan Islam. Fazlur Rahman merupakan salah satu tokoh intelektual neo-modernis. Dalam hal keagamaan, ia pernah mengalami kegelisahan intelektual yang mendalam. Menurutnya, kaum Muslim telah menutup rapat-rapat pintu ijtihad, sehingga yang terjadi adalah stagnasi intelektual yang luar biasa. Pada akhirnya Islam menjadi seperangkat doktrin yang beku dan tentu sulit untuk tampil dalam memberi jawaban-jawaban atas problem ummat di tengah gelombang modernitas. Untuk itu, ia mengambil langkah yang berbeda dalam mengungkapkan dan memformulasikan konsep sunnah dan hadis, yang hal ini merupakan respon dan bentuk kritiknya terhadap pandangan umat Islam selama ini. Konsep yang ditawarkan oleh Fazlur Rahman salah satunya berkaitan dengan hadis dan sunnah. Ia menganggap bahwa hadis dan sunnah perlu dibedakan dengan beberapa alasan yang dikemukakannya. Menurutnya hadis adalah hanya sebuah teks yang bersifat baku atau benar-benar bersumber dari Nabi Saw. Sedangkan sunnah merupakan aktualisasi atau interpretasi dari teks hadis dan harus disesuaikan dengan setting-historis ketika akan memahami sebuah hadis. Hal ini menunjukkan bahwa apa yang tertulis dalam hadis, tidak semuanya dikatakan sunnah. Tetapi, sunnah tidak pula semuanya terekam dalam hadis. Oleh karena itu, ketika hadis pernah di bakukan, maka sejak saat itu, sunnah tidak berkembang. Ia terpasung dalam kitab-kitab yang diagendakan. Penelitian ini menggunakan metode analisis-deskriptif yang di dalamnya
\end{abstract}


memuat analisa terhadap konsep fazlur rahman tentang hadis sunnah. Penelitian ini menghasilkan sebuah pandangan kritis Fazlur Rahman tentang konsep hadis dan sunnah.

Kata kunci: Hadis, Sunnah, Fazlur Rahman

\section{Pendahuluan}

Fazlur Rahman merupakan salah satu tokoh neo modernis muslim asal Pakistan yang pemikirannya menjadi bahan diskusi serius oleh kalangan pemerhati keilmuan Islam. Munculnya pemikir-pemikir Muslim liberal dunia saat ini telah menjadi wacana tersendiri di kalangan pemerhati keilmuan Islam. Pakar-pakar ini menjadi menarik untuk dicermati lantaran ide-ide yang digagasnya seringkali menyimpang, bahkan bertentangan dengan ideide yang selama ini telah dianggap sudah mapan.

Salah satu pemikiran Fazlur Rahman bermula dari kegelisahan akademis bahwa kondisi di mana kaum Muslim telah menutup rapat-rapat pintu ijtihad, sehingga yang terjadi justru kemandegan intelektual yang luar biasa. Rahman merasakan situasi ini sangat tidak kondusif untuk mengetengahkan Islam sebagai agama alternatif di tengah gelombang perubahan zaman yang kian dinamis. Jika terus dibiarkan, maka Islam hanya menjadi doktrin beku dan tidak memberikan solusi terbaik bagi problem ke-ummat-an. Dalam pandangan Rahman, perkembangan sejarah umat Islam khususnya di bidang hadis yang merupakan sumber hukum Islam kedua setelah al-Qur'an, merupakan verbalisasi dari konsep sunnah dan telah mengalami perjalanan yang sangat dramatis. Tidak saja terjadi pemalsuan hadis, akan tetapi hadis-hadis yang terformulasikan dalam beberapa kitab hadis tersebut merupakan sebuah ketentuan yang berlaku sepanjang abad tanpa perlunya penafsiran ulang terhadapnya. ${ }^{1}$

Menurut Fazlur Rahman, perlu membedakan konsep antara hadis dengan sunnah. Karena kedua komponen tersebut perlu dibedakan namun tidak bisa di pisahkan. Hadis adalah hanya sebuah teks yang bersifat pasti dan bersumber dari Nabi Saw. Sedangkan sunnah merupakan bentuk interpretasi dan aktualisasi dari teks hadis yang harus di sesuaikan dengan setting-historis. Hal ini membuktikan bahwa apa yang tertulis dalam hadis, tidak semuanya disebut sebagai sunnah. Akan tetapi, sunnah tidak pula semuanya terekam dalam hadis. Sunnah bukanlah sekadar sebuah hukum dalam bertingkah laku, melainkan suatu hukum moral yang bersifat normatif. Sedangkan hadis adalah bentuk rekaman dari sunnah itu sendiri. Oleh karena itu, ketika hadis pernah di bakukan, maka sejak saat itu, sunnah tidak berkembang. Ia terpasung dalam kitab-kitab yang sudah termaktub dalam kitab hadis.

Dalam konteks inilah Fazlur Rahman mencuat dan mengambil langkah yang berbeda dalam mengungkapkan dan memformulasikan konsep sunnah dan hadis. Hal ini pula merupakan respon dan bentuk kritiknya terhadap pandangan umat Islam selama ini. Terutama dalam menanggapi ulama' yang konservatif Pakistan terhadap konsep tersebut.

\section{Reputasi Keilmuan Fazlur Rahman}

Fazlur Rahman lahir di Distrik Hazara Pakistan pada 12 September 1919 dan meninggal dunia di Chicago pada 26 Juli $1988 .{ }^{2}$ Dia berasal dari keluarga yang alim atau

\footnotetext{
${ }^{1}$ Kurdi dkk, Hermenentika al-Qur'an dan Hadis (Yogyakarta: elsaq Press, 2010), 331.

${ }^{2}$ Ebrahim Moosa, Introduction F. Rahman, Revival and Reform in Islam: Study of Islamic Fundamentalism, di edit oleh E. Moosa (Oxford: Oneworld, 2000), 1.
} 
tergolong taat beragama dengan menganut madhhab Hanafi. Sepeti pengajuannya sendiri, keluarganya mempraktikkan ibadah sehari-hari secara teratur. Pada usis 10 tahun, ia telah menghafal al-Qur'an. ${ }^{3}$ Ayahnya Maulana Shihab al-Din adalah seorang alumnus Dar alUlum, sekolah menengah terkemuka di Deoband, India. Di sekolah ini, Shihab al-Din belajar dari tokoh-tokoh terkemuka seperti Maulana Mahmud Hassan (w1920), yang lebih popular dengan Shaikh al-Hind dan juga belajar pada seorang faqih ternama yaitu Maulana Rashid Ahmad Gangohi (w1905). ${ }^{4}$

Meskipun Fazlur Rahman tidak belajar di Dar 'Ulum, namun ia menguasai kurikulum Darse-Nizami yang ditawarkan oleh lembaga tersebut dalam kajian privat dengan ayahnya. Ini melengkapi latar belakangnya dalam memahami Islam tradisional dengan perhatian khusus pada Fiqih, Teologi, Ilmu Kalam, Hadis, Tafsir, logika (Mantiq) dan Filsafat. ${ }^{5}$ Pendidikan dasar dalam keluarga benar-benar efektif dalam membentuk watak dan kepribadiannya ketika dihadapkan langsung dengan kehidupan nyata. Menurutnya, diantara faktor yang telah membentuk karakter dan kedalamannya dalam beragama ialah pengajaran dari ibunya tentang kejujuran dan kasih sayang, dan ayahnya kerapkali mengajarkan agama dirumahnya sendiri dengan disiplin yang tinggi sehingga dia mampu menghadapi berbagai macam peradaban dan tantangan di dunia modern. ${ }^{6}$

Barangkali madhhab Hanafi yang menjadi latar belakang keluarganya ternyata juga berpengaruh dalam pembentukan pola pikirnya dikemudian hari. Madhhab ini, seperti diketahui, adalah madhhab sunni yang mengandalkan rasionalitas sehingga lebih liberal ketimbang madhhab-madhhab sunni lainnya. Namun, watak liberalis Rahman kelak, sesungguhnya juga dilatarbelakangi oleh wacana pemikiran yang ketika itu berkembang di Pakistan, seperti yang dikembangkan oleh Sayyid Ahmad Khan, Sir Sayyid Amir 'Ali dan Muhammad Iqbal.

Pada tahun 1933, Rahman di bawa ke Lahore untuk memasuki sekolah modern. Kemudian ia melanjutkan ke Punjab University, dan lulus menyandang gelar B.A. pada tahun 1940 dalam spesialisasi bahasa Arab. Dua tahun setelah itu, ia memperoleh gelar master dalam bidang yang sama, dari University tersebut. Karena menyadari bahwa mutu pendidikan tinggi Islam di India ketika itu amat rendah, Rahman akhirnya memutuskan untuk melanjutkan studi nya ke Inggris. Keputusan ini termasuk keputusan yang amat berani, sebab pada waktu itu terdapat anggapan kuat bahwa, merupakan hal yang sangat aneh jika seorang Muslim pergi belajar Islam ke Eropa dan kalau pun ada yang terlanjur kesana, maka ia akan amat susah untuk diterima kembali dinegara asalnya. Bahkan, lebih jauh tindakan berani seperti ini kerap kali mengakibatkan penindasan. ${ }^{8}$

Setelah proses panjang, tampaknya anggapan tersebut tidak menjadi penghalang bagi Rahman untuk melanjutkan studinya ke Eropa. Pada tahun 1946, ia berangkat ke Oxford University, Inggris. Dalam proses perampungannya di University ini, ia menulis Disertasi tentang psikologi Ibn Sina-yang kelak diterbitkan menjadi "Avicenna's Psychology" di terbitkan di London: Oxford University Press, 1952. Di bawah bimbingan Prof. Simon Van Den Bergh. ${ }^{9}$ Belajar di Oxford University, sebagai lembaga pendidikan yang maju di Barat,

${ }^{3}$ Fazlur Rahman, An Autobiographical The Courage of Conviction, di edit oleh Philip L. Berman (New York: Ballantine Bookes, 1985), 135.

${ }^{4}$ Ibid., Introduction F. Rahman, 1.

${ }^{5}$ Ibid. lihat pula Sibawaihi, Eskatologi Al-Ghazali dan Fazlur Rahman, Study Komparatif Epistimologi KlasikKontemporer (Yogyakarta: Islamika, 2004), 49.

${ }^{6}$ Rahman, An Autobiographical..., 135-136.

${ }^{7}$ Ibid., Eskatologi Al-Ghazali dan Fą̣lur Rahman. 50.

${ }^{8}$ Fazlur Rahman, Islam and Modernity: Transformation of an Intelectual Tradition (Chicago dan London: The University of Chicago Press, 1984), 119-120. Lihat pula Sibawaihi, Eskatologi Al-Ghazali dan Fazlur Rabman.52. 'Tbid. 54. 
Rahman berkesempatan mendalami bahasa-bahasa Barat. Jika ditelusuri dari karyakaryanya, tampak bahwa Rahman menguasai bahasa latin, Yunani, Perancis, Inggris, Jerman, Turki, Arab, Persia dan Urdu. ${ }^{10}$ Penguasaan banyak bahasa ini jelas sangat membantunya dalam upaya menggali dan memperluas wawasan keilmuannya, terutama dalam studi-studi Islam melalui penelusuran literatur-literatur keIslaman yang ditulis oleh para Orientalis dalam bahasa-bahasa yang umumnya di Eropa.

Setelah meraih gelar Doctor of Philosophy (Ph.D.) dari Oxford University pada tahun 1950, Rahman tidak langsung pulang ke negerinya, Pakistan yang baru saja merdeka beberapa tahun dan telah memisahkan diri dari India. Rahman agaknya masih merasa cemas akan fenomena masyarakat negerinya saat itu, yang agak sulit menerima seorang sarjana keIslaman yang terdidik di Barat. Karenannya, selama beberapa tahun, dia memilih untuk mengajar di Eropa. Ia memulai mengajar bahasa Persia dan filsafat Islam di Durham University, Inggris pada tahun 1950-1958.

Ketika mengajar di Universitas ini, ia merampungkan karya orisinilnya yang berjudul "Prophecy ini Islam: Philosophy and Ortodoxy, namun baru kemudian di terbitkan di London oleh George Allen dan Unwin, Ltd. Pada tahun 1958, sewaktu ia mengajar di McGill University, Kanada. Selanjutnya, atas berbagai pertimbangan, ia meninggalkan Inggris untuk menjadi Associate Professor pada bidang studi Islam di Institute of Islamic Studies McGill University Montreal, Kanada. ${ }^{11}$

Setelah tiga tahun di Kanada, Rahman memulai proyek paling ambisius dalam hidupnya, yang kemudian menjadi titik tolak dalam karirnya. Pakistan, di bawah Jenderal Ayyub Khan, mulai memperbarui usahanya pada pembentukan politik dan identitas Negara. Dalam pandangan Khan, salah satu unsur untuk membangun kembali semangat nasional adalah memperkenalkan transformasi politik dan hukum. Transformasi itu diharapkna akan membawa negara kembali pada kbittah nya, sebaga negara dengan visi dan ide Islam.

Antusiasme Rahman sendiri dalam masalah ini bisa dibuktikan dari kenyataan bahwa ia meninggalkan karir akademiknya yang bergengsi di Kanada demi tantangan yang menghadang di Pakistan. Pada awal-awal pembentukan Pusat Lembaga Riset Islam (Central Institute of Islamic Research), ia semuala menjadi professor tamu, dan kemudian menjadi direktur selama satu periode (1961-1968). Disamping sebagai direktur di lemabag ini, Rahman juga bekerja pada Dewan Penasihat Ideologi Islam (Advisory Council of Islamic Ideology), sebuah badan pembuat kebijakan tertinggi di Pakistan. Pada saat itu, posisi penting ini memberinya kesempatan untuk meninjau berlangsungnya pemerintahan dan kekuasaan dari dekat. Pada sisi lain, dengan posisi sebagai direktur lembaga riset, Rahman memprakarsai penerbitan Journal of Islamic Studies, yang hingga kini masih terbit secara berkala dan merupakan jurnal ilmiah keagamaan bertaraf Internasional. ${ }^{12}$

Jabatan direktur yang didudukinya tidak berjalan baik. Saat itu Rahman kurang mendapat restu dari kalangan ulama tradisional. Sebab, menurut mereka, jabatan direktur lembaga tersebut seharusnya merupakan hak istimewa oleh ulama yag terdidik secara tradisional. Sementara, Rahman dianggap sebagai kelompok modernis dan telah banyak terkontaminasi dengan pemikiran-pemikiran Barat. Dengan kondisi semacam ini, dapat dimaklumi jika selama kepemimpinannya, lembaga riset tersebut selalu mendapat tantangan keras dari kalangan tradisionalis. ${ }^{13}$

\footnotetext{
${ }^{10}$ Ibid. 59.

${ }^{11}$ Sibawaihi, Eskatologi Al-Ghazali dan Fąlur Rahman, 51.

12 Moosa, Introduction F. Rahman, Revival and Reform in Islam: Study of Islamic Fundamentalism, 2.

13 Sibawaihi, Eskatologi Al-Ghazali dan Fąlur Rabman. 53.
} 
Adapun puncak dari tantangan ini adalah ketika dua bab pertama dari karya pertamanya yaitu "Islam", yang diterjemahkan ke dalam bahas Urdu dan dipublikasikan pada jurnal Fikr-u-Narr. Ketegangan-ketegangan ini terus berlanjut ditambah lagi dengan ketegangan politik antara ulama tradisional dengan pemerintah yang dibawah kepemimpinan Ayyub Khan yang dapat digolngkan modernis. Sehingga pada akhirnya pada saat-saat itulah Fazlur Rahman merasa terpaksa "hengkang" dari Pakistan. ${ }^{14}$

Hijrah Rahman ke Barat kali ini ditampung sebagai dosen di Universitas California, Los Angeles pada tahun 1968. Sedangkan pada tahun 1969, ia diangkat menjadi professor dalam bidang pemikiran Islam di Universitas Chicago. Universitas ini merupakan tempat terakhirnya bekerja, hingga ia wafat. Selama menjadi pengajar di Universitas Chicago, dengan sebagai posisi Muslim modernis, Rahman telah memberikan banyak kontribusi pada ilmuwan Muslim generasi sesudahnya untuk memberikan kepercayaan diri, baik melalui publikasi, konsultasi, dakwah dan pengkaderan ilmuwan dari berbagai negara untuk belajar di bawah asuhannya. ${ }^{15}$

Selain mengajar di Universitas Chicago, Rahman juga sering di minta oleh berbagai pusat studi terkemuka di Barat untuk memberi kuliah atau berpartisipasi dalam seminarseminar Internasional yang berkaitan dengan keIslaman. Pusat studi Yahudi Universitas Connectitut di Storr, misalnya pernah memintannya pada musim semi 1981 untuk meberi kuliah tentang sikap Islam terhadap agama Yahudi. ${ }^{16}$ Penting pula diketahui bahwa Rahman adalah seorang Muslim pertama yang pernah diangkat menjadi staf pada Divinity School Universitas Chicago. Rahman juga merupakan Muslim pertama yang di anugrahi medali Giorgio Levi Della Vida yang sangat prestisius untuk studi peradaban Islam dari Gustave E. Von Grunebaum Center for Near Eastern Studies UCLA (University of California Los Angeles).

Tidak kurang dari 18 tahun lamanya, Rahman menetap di Chicago dan mengkomunikasikan ide-idenya. Samapai akhirnya Tuhan memanggilnya pada 26 Juli 1988. Kepergian sarjana pemikir Neo-Modernis ini merupakan sebuah kehilangan bagi dunia intelektual Islam kontemporer. ${ }^{17}$

\section{Perkembangan Pemikiran Fazlur Rahman}

Sebagai seorang intelektual, Rahman yang memperoleh pendidikan formal sampai jenjang tertinggi tentu mempunyai sejarah sendiri dalam kaitannya dengan perkembangan pemikirannya. Dalam perkembangan corak keagamaan, Fazlur Rahman juga mempunyai perkembangan corak dalam pemikirannya. Hingga, puncak dari perkembangan tersebut dapat memberikan solusi bagi kritis intelektual (sense of intellectual crises) nya. Berdasarkan tulisan-tulisannya, tampaknya Rahman hanya mengalami perkembangan minat keagamaan atau corak intelektualitas keagamaan.

Pada dekade 1950 an, corak intelektualisme Rahman masih diwarnai oleh Islam historis. Pernyataan ini tentu saja didasarkan atas perkembangan yang tampak dari tulisantulisannya. Tetapi, mencermati ide-ide yang dimunculkan dalam karya-karyanya pada masa ini, kajiannya sudah menunjukkan sikap yang kritis-analitis. Munculnya karya prophecy in Islam (1958), misalnya dilatarbelakangi oleh kurangnya perhatian yang diberikan para sarjana

\footnotetext{
14 Ibid. 60 .

${ }^{15}$ Ibid. 75 .

${ }^{16}$ Ibid., 54. Hasil kuliah ini dirakit dalam "Islamic Attitude Toward Judaism”, dimuat dalam The Muslim World, LXXII, No 1 (Januari 1982), 1-13.

${ }^{17}$ Abdou Filali Ansary, Reformer Islam: Une Introduction aux debats Contemporains, Terj. Machasin dengan judul “Pembaruan Islam Dari mana Hendak Ke Mana?” (Bandung: Mizan Media Utama, 2009), 210.
} 
modern terhadap bidang religio-filosofis Islam yang sangat penting tentang doktrin kenabian. ${ }^{18}$

Pada masa-masa ini kajian yang dilakukan Rahman memang banyak berorientasi pada penelusuran sejarah pemikiran Islam klasik maupun modern. Yang terakhir ini menjadi perhatian Rahman terutama setelah ia melihat aspek-aspek modernism para pembaru. Menurut asumsi sementara Rahman bahwa pemikiran filosofis Islam pada masa awal modern berjalan goyah sehingga konsentrasinya hanya pada masalah-masalah legal dan sosial-praktis.

Perhatian Rahman pada masa-masa awal perkembangan pemikirannya ini tidaklah terbatas pada aspek religio-filofis modernisme Islam, sebab ia juga menganalisis secara kritis perkembangan-perkembangan internal Islam periode modern. Dalam hal kenegaraan (Islam) misalnya, Rahman menyatakan bahwa modernis di bidang ini juga belum mampu menyusun suatu teori yang konsisten tentang negara Islam yang akan mengharmoniskan konsep-konsep demokratis Barat dengan cita-cita Islam. ${ }^{19}$ Dengan demikian, latar belakang politik kenegaraan ini mewarnai gagasan-gagasan Rahman selanjutnya hingga ia kembali ke Pakistan.

Sebagaimana yang telah dikemukakan, bahwa Pakistan pada awal perkembangannya adalah ajang kontroversi diantara kaum modernis dan di satu pihak dengan kaum tradisionalis dan fundamentalis di pihak lain. Situasi demikian sangat kondusif bagi pengembangan pemikiran Rahman, disamping kontaknya yang intens dengan Barat ketika ia menetap di Eropa dan Amerika. Keterlibatan Rahman dalam hal ini ditandai dengan publikasi artikel-artikelnya dalam jurnal "Islamic Studies” yang dirintisnya mulai Maret 1962 sampai Juni 1963 yang kemudian dibukukan menjadi "Islamic Methodology in History". ${ }^{20}$

Karya ini jelas muncul sebagai upaya untuk memberi definisi "Islam" bagi Pakistan, di samping sebagai respon terhadap kecenderungan "ingkar sunnab" yang berkembang disana, dan juga sebagai respon terhadap situasi kesarjanaan Barat sehubungan dengan konsep Sunnah Nabi dan evolusi hadis. Sebagaimana kalangan modernis lainnya, Rahman melihat bahwa kebutuhan reformulasi gagasan politik, moral dan cita-cita spiritual Islam sangat bergantung pada penilikan ulang hadis. Pemikiran inilah yang kemudian dielaborasi dalam Islamic Methodology, tetapi tentu saja sangat berat diterima oleh kalangan fundamentalis atau tradisionalis. ${ }^{21}$

Arah pemikiran keagamaan demikian menjadi makin matang ketika ia menghasilkan bukunya yang berjudul Major Themes of The Qur'an. Dalam buku ini Rahman mengetengahkan secara sistematis delapan tema pokok Qur'an yang tertata dalam urutan sebagai berikut; Tuhan, manusia sebagai individu, manusia sebagai anggota anggota masyarakat, alam semesta, kenabian dan wahyu serta lahirnya masyarakat Muslim. Dari tema-tema yang diangkat itu terlihat cakupan wawasan yang hendak dikembangkan Rahman dalam membingkai gagasan-gagasan pembaruannya. Setidaknya dapat ditafsirkan, itulah respon Rahman setelah mengamati kajian-kajian al-Qur'an yang berkembang waktu itu yang di nilainya kurang memenuhi kebutuhan masyarakat. ${ }^{22}$

Melalui karya ini Rahman berhasil membangun kajian filosofis yang tegar untuk perenungan kembali makna dan pesan al-Qur'an bagi kaum Muslimin kontemporer. Lebih

\footnotetext{
${ }^{18}$ Fazlur Rahman, Islam (Chicago: University of Chicago Press, 1979), ix. Lihat juga Sibawaihi, Eskatologi AlGhazali dan Fazlur Rahman. 55.

${ }^{19}$ Ibid., 56.

${ }^{20} \mathrm{Ibid}, 70$.

${ }^{21}$ Ibid. 74.

${ }^{22}$ Ahmad Amir Aziz, Pembaruan Teologi Perspektif Modernisme Mubammad Abdub dan Neo-Modernisme Fazlu Rabman (Yogyakarta: Teras, 2009), 73.
} 
jauh lagi, ia menekankan perlunya pemahaman latar belakang sosio-historis ajaran-ajaran hukum al-Qur'an guna memahami ideal moral atau rasio-legisnya. Rasio-legis adalah esensi hukum, sedang legislasi tersebut merealisasikan rasio-legisnya secara sepenuhnya dan tepat. Jika tidak, maka hukum harus diubah. Ketika situasi berubah sehingga hukum gagal mencerminkan rasio-legisnya, maka hukum harus diubah. ${ }^{23}$

Corak pemikiran Rahman dapat diketahui melalui karyanya yang berjudul "Islam". Buku ini tidak menyajikan satu bidang tertentu dalam kajian Islam tetapi lebih merupakan review secara singkat dan padat atas seluruh dimensi penting dalam sejarah perkembangan Islam selama empat belas abad, baik dari aspek al-Qur'an, hadis, tasawuf, hukum, teologi dan gerakan pembaruan. Pada bagian penghujung buku ini, Rahman mengadakan evaluasi kritis terhadap warisan-warisan kesejarahan Islam dan suatu solusi berupa seruan untuk mengadakan reformulasi atas warisan tersebut. Inilah yang menurut Rahman dapat melindungi nilai-nilai abadi Islam sambil meninggalkan akumulasi-akumulasi non Islami yang telah melekat dalam corak kultural kaum muslim. ${ }^{24}$

Pemikiran Rahman pada periode Pakistan ini sebelum ia pindah ke USA lebih di dominasi oleh wacana ke moderenan dalam memberikan ulasan, penilaian dan pendiriannya atas berbagai masalah. Dalam aspek teoritis kajian Rahman banyak diarahkan pada persoalan-persoalan religio-filosofis yang hendak mencari jalan keluar dari kemelut ketegangan antara jenis pemahaman filosofis dan non-filosofis. Sedangkan dalam aspek praksis, Rahman secara intens terlibat dalam usaha pencarian identitas keIslaman bagi negeri Pakistan. ${ }^{25}$

Kedua sisi aspek teoritis dan praksis ini tidak berhasil dikembangkan secara maksimal oleh Rahman karena suasana Pakistan yang kurang kondusif. Seperti disinggung sebelumnya bahwa dalam pencarian identitas keIslaman bagi Pakistan, terdapat kelompokkelompok yang masing-masing memperjuangkan pendiriannya. Namun sayang sekali berbagai kelompok ini tidak dapat bekerja sama dan saling menghargai, sebaliknya justru menjadi saling bersengketa.

Dengan demikian terdapat alasan yang kuat mengapa Rahman harus meninggalkan negeri asalnya Pakistan. Pertama karena tidak adanya jaminan kebebasan intelektual, dan kedua karena profesinya lebih mendapat tempat di negeri Barat. Pada kenyataannya Rahman merasa cocok di negara Barat meskipun dpat disebut sebagai sarang orientalis. Kecocokannya itu ditunjukkan oleh keseriusannya dalam melanjutkan telaah-telaah kritis dan antisipatif terhadap problem-problem dan masa depan Islam dengan ditunjukkan melalui artikel dan buku-bukunya yang terbit kemudian. ${ }^{26}$

Pada periode Chicago inilah terlihat perkembangan intelektual yang berarti dalam diri Rahman. Satu karya penting yang dihasilkan adalah bukunya yang berjudul "Islam and Modernity: Transformation of an Intellectual Tradition”. Buku ini memperlihatkan secara jelas betapa intensnya Rahman dalam meberi alternative dan menata masa depan Islam dan umatnya. Sebagian besar isi buku ini berkisar pada kajian kritis Rahman mengenai sejarah intelektual dan pendidikan Islam sejak periode klasik hingga dewasa ini. Pada bagian akhir karya tersebut ia mencatat perlunya rekonstruksi intelektualisme Islam dan untuk itu ia menawarkan beberapa konsep dasar. Pertama, umat Islam harus mampu membedakan antara Islam normative dan Islam historis. Kedua, perlunya rekonstruksi ilmu-ilmu Islam yang meliputi teologi, hukum, etika, filsafat dan ilmu-ilmu lainnya. ${ }^{27}$

\footnotetext{
23 Sibawaihi, Eskatologi Al-Ghazali dan Fazlurrahman. 59.

${ }^{24}$ Aziz, Pembaruan Teologi Perspektif Modernisme Muhammad Abduh dan Neo-Modernisme Fazlu Rabman, 77.

25Ibid. 80.

${ }^{26}$ Ibid., 79 .

${ }^{27}$ Ibid. 85.
} 
Menurut Rahman, pemikiran Islam kontemporer adalah sangat penting, jika Islam hendak di revitalisasikan serta jika kaum Muslim hendak menjadi suatu kekuatan yang dahsyat dan produktif yang mampu membentuk masa depannya kembali. Dengan demikian, puncak perkembangan pemikiran Rahman pada dasranya diawali dari kedaran bahwa Islam dewasa ini tengah menghadapi krisis yang sebagian berakar pada Islam sejarah, serta sebagian lagi dikarenakan penetrasi pengaruh-pengaruh Barat yang menampilkan dirinya dalam bentuk tantangan modernitas. Sehingga Rahman berupaya mengelaborasi terapi dan solusi terhadap krisis tersebut.

\section{Pemikiran Hadis dan Sunnah Perspektif Fazlur Rahman}

Fazlur Rahman, seorang intelektual yang memposisikan dirinya pada barisan neomodernisme, mengawali sepak terjangnya dalam percaturan pemikiran Islam pada era kontemporer ini dengan merasakan kegelisahan akademik, yang juga dirasakan oleh banyak kalangan Muslim, yaitu tertutupnya rapat-rapat pintu ijtihad. Hal ini akan membawa implikasi pada stagnasi intelektual (pemikiran) yang luar biasa di kalangan umat Islam. Bagi Rahman, untuk keluar dari kondisi ini perlu membangun seperangkat metodologi yang sistematis dan komprehensif, khususnya terkait dengan penggalian terhadap sumbersumber ajaran Islam, yakni al-Qur'an dan Hadis.

Hadis dalam kapasitasnya sebagai fakta sejarah dari proses transmisi sanad hingga hingga munculnya pembukuan hadis secara besar-besaran telah mengalami proses panjang dan alot. Mula-mula tidak ada masalah berkaitan dengan hadis Nabi, namun kemudian muncul suatu fenomena penyebarab hadis-hadis palsu, yang akhirnya "memaksa" para ulama' (terutama ahli hadis) untuk melakukan penyeleksian hadis-hadis yang benar-benar bersumber dari Nabi Saw. Dalam rangka penyeleksian ini, dibuatlah teori-teori yang dapat menjamin tingkat vaiditas suatu hadis. Hal ini sangat wajar mengingat posisi hadis Nabi sebagai penjelas bagi al-Qur'an dalam mengambil istinbath hukum.

Namun, dalam perkembangan sejarah umat Islam selanjutnya hadis yang merupakan verbalisasi dari konsep sunnah telah mengalami perjalanan yang sangat dramatis, tidak saja terjadi pemalsuan sebagaimana yang dijelaskan sebelumnya. Akan tetapi hadis-hadis yang terformulasikan dalam beberapa kitab hadis tersebut dianggap sebagai sebuah ketentuan yang bersifat pasti, kaku dan tertutup. Dengan kata lain sebuah ketentuan yang berlaku sepanjang abad tanpa perlunya penafsiran ulang terhadapnya. ${ }^{28}$ Pandangan ini akan melumpuhkan usaha dalam berijtihad di kalangan umat Islam dan terjadinya stagnasi serta ke-mandeg-an dalam pemikiran Islam. ${ }^{29}$

Dalam konteks inilah Rahman mulai mencuat dan mengambil langkah yang berbeda dalam mengungkapkan dan memformulasikan konsep sunnah dan hadis. Hal ini pula merupakan respon dan bentuk kritiknya terhadap pandangan umat Islam selama ini. Terutama dalam menanggapi ulama' yang konservatif Pakistan terhadap konsep tersebut. Seiring dengan hal itu, konsep Rahman tersebut secara berkelindan merupakan respon dari bantahan terhadap pandangan orientalis sebagaimana tuduhan Ignaz Goldziher terhadap konsep sunnah dan hadis Nabi Saw yang mana pada umumnya dan secara garis besar orientalis berpandangan bahwa hadis Nabi Saw tidak memiliki akar historis dari Nabi Saw dan hadis Nabi Saw. Merupakan kreasi ulama' abad ke 2 dan ke $3 \mathrm{H}^{30}$

Untuk menjawab tuduhan tersebut, Rahman terlebih dahulu mengemukakan konsep sunnah. Dalam pandngan Rahman, ada dua arti sunnah yang saling berhubungan

\footnotetext{
${ }^{28}$ Kurdi dkk, Hermeneutika al-Qur'an dan Hadis, 331.

${ }^{29}$ Ibid. 335.

${ }^{30}$ Ibid, 340 .
} 
erat namun harus dibedakan. Pertama, sunnah berarti perilaku Nabi Saw. dan karenanya ia memperoleh sifat normatifnya. ${ }^{31}$ Dalam hal ini sunnah Nabi Saw atau sunnah normatif harus dipandang sebagai sebuah konsep teladan, pengayom dan pedoman yang umum dan terbungkus dalam ketentuan yang bersifat khusus.Pandangan ini membawa konsekuensi logis, yaitu perlu memahami perilaku Nabi dalam bingkai konteks dan kerangka historissosiologisnya. ${ }^{32}$ Dengan kata lain, sunnah Nabi perlu dipandang sebagai sebuah teladan (pengayoman), bukan kandungan khusus yang bersifat mutlak. ${ }^{33}$

Kedua, sepanjang tradisi (perilaku Nabi) tersebut berlanjut secara "diam-diam" dan non verbal, maka kata sunnah ini juga diterapkan pada kandungan aktual perilaku generasi Nabi, sepanjang perilaku tersebut dinyatakan sebagai meneladani pola perilaku Nabi. ${ }^{34}$ Untuk yang terakhir ini sunnah dengan sendirinya pasti mengalami perubahan dan sebagian besar berasal dari praktek aktual masyarakat Muslimin. ${ }^{35}$ Adapun perubahan-perubahan yang terjadi ini adalah hasil dari kesimpulan atau interpretasi para sahabat Nabi, yang mana kemudian bermetarmorfosis menjadi sunnah "yang hidup" dan "sunnah aktual"

Pandangan Rahman terhadap konsep sunnah di atas, dapat diungkapkan bahwa sunnah Nabi lebih tepat jika dikatakan sebagai sebuah konsep pengayoman dan teladan yang mana mempunyai sebuah kandungan khusus yang memiliki prinsip umum, daripada ia mempunyai sebuah kandungan khusus yang dipegang dan diterapkan apa adanya. Hal ini secara teoritis dapat disimpulkan secara langsung dari kenyataan bahwa sunnah adalah sebuah terma perilaku (behaviral) yang bercorak situasional, karena didalam prakteknya tidak ada dua buah kasus yang benar-benar sama latar belakang situasionalnya, secara moral, psikologis dan material. Maka sunnah Nabi tersebut haruslah dapat dikembangkan, diinterpretasikan, dan diadaptasikan. Pada bagian ini sunnah secara terus menerus mengalami evolusi dari generasi ke generasi. ${ }^{36}$

Menurut Rahman, ada persoalan penting yang harus dikupas terlebih dahulu untuk mencermati apa yang dimaksud dengan hadis atau sunnah. Konsepsi Rahman tentang hadis dan sunnah ini berawal dari respon kritis yang diberikan terhadap pandangan kesarjanaan Barat. Diantara sarjana Barat yang termasuk dalam lingkup kritisisme Rahman dalam hal ini adalah Ignaz Goldziher dan Margoliouth. ${ }^{37}$ Goldziher menilai bahwa merupakan pekerjaan yang amat sukar untuk menentukan hadis-hadis yang benar-benar murni dari Nabi Saw. Mereka menganggap teks-teks hadis selama ini hanya merupakan kreasi ulama' abad ke-2 dan ke-3 H yang kemudian muncul dalam masyarakat Islam hingga sekarang. ${ }^{38}$ Margoliouth bahkan lebih ekstrem lagi, yakni menganggap bahwa hadis Nabi Muhammad Saw. sama sekali tidak meninggalkan hadis ataupun sunnah, melainkan hanya kebiasaan-kebiasaan bangsa Arab pra Islam yang telah dimodifikasi oleh al-Qur'an. ${ }^{39}$

Secara definitif, hadis dalam pemahaman Rahman tidak berbeda dari pemahaman pakar-pakar lainnya. Hadis merupakan kumpulan informasi mengenai segala perkataan, perbuatan dan ketetapan Nabi Muhammad Saw sedangkan sunnah adalah sebuah konsep perilaku baik yang diterapkan pada aksi-aksi fisik maupun aksi mental dan lebih jauh idak hanya tertuju pada sebuah aksi sebagaimana adanya tetapi selama aksi itu secara aktual

31 Fazlur Rahman, Islam, Terj Senoaji Saleh (Jakarta: Bumi Aksara, 1987), 85. Lihat juga Kurdi dkk, Hermeneutika al-Qur'an dan Hadis, 331.

32 Ibid., 10.

33 Ibid., 12.

${ }^{34}$ Kurdi dkk, Hermeneutika al-Qur'an dan Hadis, 332. Lihat juga Fazlur Rahman, Islam. 85-86.

35 Ibid. 360.

${ }^{36}$ Ibid., 333.

${ }^{37}$ Sibawaihi, Eskatologi Al-Ghazali dan Fąlurrahman. 181.

${ }^{38}$ Ibid. lihat juga Kurdi dkk, Hermenentika al-Qur'an dan Hadis, 331.

${ }^{39}$ Ibid. 339. 
berulang atau mungkin seringkali berulang kembali. ${ }^{40}$ Dengan demikian, apabila umumnya para ulama' mendefinisikan hadis dan sunnah secara sama, yaitu sebagai apa saja yang di sandarkan kepada Nabi Saw berupa ucapan, perbuatan, ketetapan atau sifat fisik, akhlak dalam konsepsi Rahman ternyata berbeda.

Hal ini menunjukkan bahwa apa yang tertulis dalam hadis, tidak semuanya dikatakan sunnah. Tetapi sunnah tidak pula semuanya terekam dalam hadis. Sunnah bukan sekadar sebuah hukum tingkah laku, melainkan juga merupakan hukum moral yang bersifat normatif. Sedangkan hadis adalah bentuk rekaman dari sunnah itu sendiri. Oleh karena itu, ketika hadis pernah di bakukan, maka sejak saat itu, sunnah tidak berkembang. Ia terpasung dalam kitab-kitab yang diagendakan. Opini masyarakat Muslim dibentuk agar memahami bahwa dengan kitab-kitab kumpulan hadis itulah kaum Muslim dapat mmenjalankan sunnah dengan baik. ${ }^{41}$

\section{Tanggapan Fazlur Rahman Atas Tuduhan Orientalis}

Selanjutnya dalam menjawab tuduhan dan pandangan para orientalis bahwa hadis Nabi yang banyak dijadikan rujukan oleh kaum muslimin ternyata telah kehilangan keotentikannya sebagai sumber hukum Islam. Karena dalam sejarah terbukti bahwa kodifikasi dan penerapan isnad dalam sistem periwayatan hadis Nabi ternyata baru dilakukan pada abad ke-3 H. fenomena ini bagi orientalis menunjukkan bahwa hadis tersebut adalah karangan dari ulama' pada zaman tertentu. Bagi Rahman, banyak pandangan dan usaha orientalis yang lihai telah dikerahkan untuk mendiskreditkan keseluruhan batang tubuh hadis. Mereka menganggap begitu Nabi Muhammad tampil, maka semua perbuatan dan tingkah lakunya menjadi sunnah bagi masyarakat Muslim.

Berkaitan dengan penjelasan konsep sunnah para orientalis di atas, Rahman mempunyai dua keberatan, yaitu keberatan logika dan historis. Keberatan logikanya adalah berkaitan dengan Ignaz yang menganggap sunnah di satu sisi sebagai praktek normatif dari masyarakat Muslim awal dan pada sisi lain ia anggap sebagai praktek yang hidup serta aktual. Karena bagi Rahman kedua hal ini harus dibedakan, karena dua konsep ini memang berbeda. Sedangkan keberatan historisnya adalah Nabi tidak meninggalkan warisan apapun selain al-Qur'an. ${ }^{42}$ Kedua keberatan ini di jawab Rahman dengan menunjukkan kesalahan mereka terhadap pemahaman konsepsi sunnah.

Dalam hal ini, Rahman menyanggah pandangan orientalis terhadap sunnah dengan menegaskan sebagai berikut ${ }^{43}$ :

1. Bahwa sementara kisah perkembangan sunnah di atas hanya benar sehubungan dengan kandungannya, tetapi tidak benar sehubungan dengan konsepnya yang memiliki validitas dan operatif, sejak awal sejarah Islam hingga masa kini.

2. Kandungan sunnah yang bersumber dari Nabi tidak banyak jumlahnya dan tidak dimaksudkan bersifat spesifik dan mutlak.

3. Konsep sunnah sesudah Nabi wafat tidak mencakup sunnah Nabi, tapi juga penafsiran-penafsiran terhadap sunnah Nabi tersebut.

Ungkapan Rahman di atas secara garis besar bisa dimaknai bahwa disatu sisi ia sepakat dan menyetujui pandangan orientalis yang berkaitan dengan kandungan sunnah Nabi yang mengalami evolusi dari generasi ke generasi. Namun di sisi lain dia tidak sepakat dan membantah konsep sunnah yang di bangun orientalis bahwa sunnah Nabi tidak

\footnotetext{
${ }^{40}$ Fazlur Rahman, Islamic Methodology in History (Karachi: Central Institute of Islamic Research, 1965), 1.

${ }^{41}$ Ibid., 12.

${ }^{42}$ Fazlur Rahman, Islam. 71.

${ }^{43}$ Kurdi dkk, Hermeneutika al-Qur'an dan Hadis , 335-336.
} 
memiliki akar historis dari Nabi atau hasil kreasi kaum Muslimin belakangan. Memang, Rahman mengakui bahwa istilah sunnah mungkin mula-mula tidak dirumuskan sebagai suatu "konsep yang sadar" atau di program dari awal. ${ }^{44}$

Akan tetapi hal itu bukan berarti bahwa ia baru muncul dikemudian hari (abad ke2), karena dalam kenyataannya, Nabi merupakan sumber pedoman atau teladan bagi masyarakat Muslim sejak semula. ${ }^{45}$ Karena sunnah menurut Rahman berarti tingkah laku yang merupakan teladan dan akan atau harus diikuti oleh seluruh umat Islam.

Dari semua paparan dari pemikiran Rahman terhadap hadis ataupun sunnah, menurut analisa penulis bahwa dari beberapa fakta sejarah yang membuktikan kegelisahan intelektual Rahman atas problematika umat Islam pada umumnya. Mereka menganggap bahwa apa yang telah terbakukan dalam kitab-kitab hadis adalah suatu yang bersifat mutlak dan tidak bisa di rubah. Sehingga dengan pengertian tersebut, maka Islam hanyalah seperangkat doktrin beku dan tidak dapat memberi jawaban atas problem-problem masyarakat yang kian berkembang. Hal inilah menjadi pemicu Rahman untuk menelaah kembali konsep sunnah atau hadis.

Hasilnya adalah Rahman membedakan antara hadis dan sunnah. Menurutnya hadis adalah hanya sebuah teks yang bersifat baku atau benar-benar bersumber dari Nabi Saw. Sedangkan sunnah merupakan aktualisasi atau penafsiran dari teks hadis dan harus di sesuaikan dengan setting-historis ketika akan memahami sebuah hadis. Dengan demikian, hadis dan sunnah berjalan beriringan tanpa menafikan salah satunya. Dan dari situlah akan tercipta pemahaman sunnah atau hadis secara obyektif. Dalam hal ini menurut penulis, perbedaan arti tersebut merupakan bantahan juga terhadap tuduhan orientalis sebagaimana Ignaz Goldziher yang menganggap bahwa hadis adalah hasil kreasi para ulama' abad ke 2 atau ke 3 .

\section{Konsep Hadis “ Informal- Semi Formal- Formal”}

Fazlur Rahman juga mengemukakan teori perkembangan hadis yaitu, hadis "informal-semiformal-formal". Mengawali pandangannya tentang konsep ini, Rahman menyatakan bahwa hadis mula-mula muncul tanpa dukungan sanad pada sekitar perputaran abad ke $1 \mathrm{H} \cdot{ }^{46} \mathrm{Namun}$ terdapat dugaan yang kuat bahwa fenomena hadis telah ada sejak awal perkembangan Islam (masa Nabi Saw), mengingat posisi Nabi Saw adalah sumber pedoman masyarakat muslim pada saat itu. Hanya saja, perkembangan konsep hadis pada saat ini bersifat informal. ${ }^{47}$

Dalam arti pembicaraan Nabi hanyalah bagian dari peristiwa yang terjadi dalam kehidupan keseharian mereka. Proses periwayatan (transmisi verbal) tentang Nabi bukanlah suatu kesengajaan demi orientasi praktis, karena satu-satunya peranan hadis yang memberikan bimbingan dalam praktek actual masyarakat muslim sudah terpenuhi oleh Nabi Saw.

Namun setelah Nabi Saw wafat dan pada masa sahabat dan tabi'in, perkembangan konsep hadis menjadi berubah dari kondisi informal menjadi semi-formal. Hal ini disebabkan oleh karena generasi yang baru menanyakan perihal perilaku Nabi Saw. Pada masa inilah fenomena hadis berubah menjadi suatu kesengajaan. Hadis pada tahap ini merupakan sarana penyebaran sunnah Nabiyang mempunyai tujuan praktis, yakni suatu

\footnotetext{
${ }^{44}$ Fazlur Rahman, Islamic Methodology in History, 72.

${ }^{45}$ Ibid., 69.

46 Ibid. Lihat Rahman, Islam, 68.

47 Ibid. 96.
} 
yang dapat menciptakan dan dapat dikembangkan menjadi praktek masyarakat muslim. ${ }^{48}$ Sehingga pada masa ini pun penafsiran hidup yang bersifat dinamis dengan proses interpretasi yang terus menerus terhadapnya menjadi baku dan tertutup serta dianggap sebagai keputusan dan ketentuan yang bersifat final demi sebuah alasan untuk keseragaman umat Islam.

\section{Penutup}

Fazlur Rahman yang memposisikan dirinya sebagai barisan intelektual Muslim neomodernis berpandangan, bahwa perlu membedakan antara hadis dan sunnah. Menurutnya, pemahaman yang kaku akan menimbulkan kesalahan yang fatal. Ia beranggapan bahwa pintu ijtihad masih terbuka lebar sesuai dengan kemampuan yang memadai. Berkaitan dengan konsep hadis dan sunnah menurut Fazlur Rahman, bahwa kontekstualisasi hadis sangat diperlukan. Artinya Nabi Saw mempertimbangkan kondisi atau lingkungan yang mengitarinya. Sehingga doktrin-doktrin keIslaman bisa diterapkan kapanpun dan di manapun. Dari sinilah konsep sunnah diterapkan serta tidak bersifat beku dan kaku. Dengan adanya kontekstualisasi tersebut, maka akan tercipta pemahaman-pemahaman terhadap hadis secara komprehensif.

\section{Daftar Pustaka}

Ansary, Abdou Filali. Reformer Islam: Une Introduction aux debats Contemporains, Terj. Machasin dengan judul "Pembaruan Islam Dari mana Hendak Ke Mana?". Bandung: Mizan Media Utama, 2009.

Aziz, Ahmad Amir. Pembaruan Teologi Perspektif Modernisme Mubammad Abdub dan NeoModernisme Fazlur Rahman. Yogyakarta: Teras, 2009.

Ismail, Syuhudi. Hadis Nabi Yang Tekstual Dan Kontekstual. Jakarta: Bulan Bintang, 1994.

Kurdi dkk, Hermeneutika al-Qur'an dan Hadis. Yogyakarta: elsaq Press, 2010.

Moosa, Ebrahim. Introduction F. Rahman, Revival and Reform in Islam: Study of Islamic Fundamentalism, di edit oleh E. Moosa. Oxford: Oneworld, 2000.

Rahman, Fazlur. An Autobiographical the Courage of Conviction, di edit oleh Philip L. Berman. New York: Ballantine Bookes, 1985.

. Islam and Modernity: Transformation of an Intelectual Tradition. Chicago dan London: The University of Chicago Press, 1984.

. Prpphecy in Islam: Philosophy and Ortodoxy, terj, Ahsin Muhammad, Kontroversi Kenabian dalam Islam: Antara Filsafat dan Ortodoksi. Bandung: Mizan, 2003.

. Islam. Chicago: University of Chicago Press, 1979.

Islamic Methodology in History. Karachi: Central Institute of Islamic Research, 1965.

${ }^{48}$ Ibid. 100. 
Sibawaihi. Eskatologi Al-Gbazali dan Fą̧lur Rahman, Study Komparatif Epistimologi KlasikKontemporer. Yogyakarta: Islamika, 2004. 